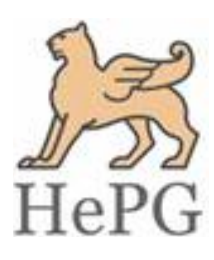

ISSN: 2348-1900

Plant Science Today

http://www.plantsciencetoday.online

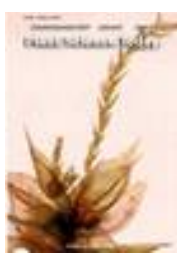

OPEN

Review Article

\title{
Phytotherapy for seizure: An overview of the most important indigenous Iranian medicinal plants with anticonvulsant properties
}

\author{
Behrooz Farzan $^{1}$, Somayeh Shahsavari ${ }^{2}$, Saber Abbaszadeh ${ }^{3,4,5}$ \& Hassan Teimouri ${ }^{* 1}$ \\ ${ }^{1}$ Department Of Anesthesiology, Lorestan University of Medical Sciences, Khorramabad, Iran \\ ${ }^{2}$ Department of Medicinal Plants, Biotechnology and Medicinal Plants Research Center, Ilam University of Medical Sciences, Ilam, Iran \\ ${ }^{3}$ Department of Medicinal Plants, Razi Herbal Medicines Research Center, Lorestan University of Medical Sciences, Khorramabad, Iran \\ ${ }^{4}$ Student Research Committee, Lorestan University of Medical Sciences, Khorramabad, Iran \\ ${ }^{5}$ Department of Biochemistry, Hepatitis Research Center, Lorestan University of Medical Sciences, Khorramabad, Iran
}

\section{Article history}

Received: 18 April 2019

Accepted: 19 May 2019

Published: 01 October 2019

\section{Publisher}

Horizon e-Publishing Group

\section{*Correspondence}

Hassan Teimouri

花assan teimouri@yahoo.com

\begin{abstract}
The statistics show that more than fifty million people worldwide suffer from seizure and epilepsy, and most of them are resistant to antiepileptic drugs. The causes of seizure attacks are different, including various diseases of the nervous system, infections, tumors, brain trauma, congenital diseases, fever, toxicity and metabolic factors. Currently, drugs such as phenytoin, phenobarbital, carbamazepine, valproic acid and diazepam are used to treat epileptic seizures, which in turn lead to side effects. Studies have shown that the use of natural and herbal antiseptic agents has beneficial and protective effects. In this review article, the most important indigenous Iranian medicinal plants used to treat seizures are reported. Information to conduct this review article has been obtained using the search terms seizure, neurological lesion, phytotherapy, Iran, medicinal plants, extracts and essential oils to retrieve articles indexed in databases such as Scopus, Scientific Information Database, Magiran, Google Scholar and other Persian databases. The relevant articles were further reviewed for medicinal plants with anticonvulsant properties. Based on the results, medicinal plants such as Peganum harmala, Lavandula officinalis, Matricaria chamomilla, Tanacetum sonbolii, Launaea acanthodes, Ocimum basilicum, Salvia sahendica, Ruta graveolens, Elaeagnus angustifolia, Ziziphora tenuior, Heracleum persicum and Scrophularia striata are among the most important medicinal plants in Iran with anticonvulsant effect.
\end{abstract}

Keywords: seizure; neural lung; medicinal plants; Iran

Citation: Farzan B, Shahsavari S, Abbaszadeh S, Hassan Teimouri H. Phytotherapy for seizure: An overview of the most important indigenous Iranian medicinal plants with anticonvulsant properties. Plant Science Today 2019; 6(4):367-372. https://doi.org/10.14719/pst.2019.6.4.557

Copyright: (c) Farzan et al (2019). This is an open-access article distributed under the terms of the Creative Commons Attribution License, which permits unrestricted use, distribution, and reproduction in any medium, provided the original author and source are credited (https://creativecommons.org/licenses/by/4.0/).

Indexing: Plant Science Today is covered by Scopus, Web of Science, BIOSIS Previews, ESCI, CAS, AGRIS, CABI, Google Scholar, etc. Full list at http://www.plantsciencetoday.online

\section{Introduction}

Epilepsy is a common neurological disorder characterized by unpredictable and periodic seizures (1). The statistics show that more than fifty million people worldwide suffer from seizure and epilepsy, and most of them are resistant to antiepileptic drugs. (2). Seizure, which is a limited 
event in the brain, results from abnormal firing of brain neurons (3). Major factors leading to seizure include brain trauma, cerebral ischemia, and brain infections $(4,5)$. Experiments conducted on animals, seizure-inducing materials act via different mechanisms, and it is argued that the glycine receptor acts as an inhibitory transmitter (6). The causes of seizure attacks are various, including different diseases of the nervous system, infections, tumors, brain trauma, congenital diseases, fever, toxicity and metabolic factors (7). The main point in treating seizure and epilepsy is the need for long-term treatment, which will further provide the conditions for the development of side effects of medications. Therefore, paying attention to traditional medicine and herbal drugs with the goal of achieving lowrisk drugs with minimal side effects is becoming more apparent $(8,9)$. Drugs such as phenytoin, phenobarbital, carbamazepine, valproic acid, and diazepam are commonly used to treat epileptic seizures, which, in turn, lead to certain side effects (10), including rash, jaundice, sore throat, fever, simple bleeding, bruising, and pethecia bleeding (11-13). Medicinal plants have been used to control and treat diseases for centuries, and their appropriate therapeutic effects with less side effects have been proven over the years (14-19). Studies have shown that the use of anticonvulsants of natural and herbal origin has beneficial and protective effects (20).

Anti-epileptic drugs have side effects; while it is a known fact that medicinal herbs are safe and available in natural sources. In traditional medicine, for the formulation of a synthetic drug, chemical compounds in a single plant or those in different parts of several plants are utilized (16, 17). From ancient times, medicinal plants were fruitfully utilized with less complications and are found to be a suitable alternative for the treatment of diseases $(16,17)$. Therefore, the identification of medicinal herbs that can form as a remedial measure for the seizure can lead to the production of anticonvulsant herbal medicines. Hence, much attention have been paid to traditional medicine and herbal drugs that becomes more obvious in attaining low-risk drugs with minimal side effects. In this respect, the present review is focusing on the most important indigenous medicinal plants used in the treatment of seizures.

\section{Methodology}

Information to conduct this review article has been obtained using the search terms seizure, neurological lesion, phytotherapy, Iran, medicinal plants, extracts and herbs to retrieve articles indexed in databases such as Scopus, Scientific Information Database, Magiran, Google Scholar and other Persian databases. Altogether, 16 were obtained from the search, of which 4 were deleted due to ineffective results, invalid magazines, and irrelevance. Finally, 12 articles were considered for review and the results were analysed. The relevant articles were further reviewed for medicinal plants with anticonvulsant properties.

\section{Results}

Based on the results, medicinal plants such as Peganum harmala, Lavandula officinalis, Matricaria chamomilla, Tanacetum sonbolii, Launaea acanthodes, Ocimum basilicum, Salvia sahendica, Ruta graveolens, Elaeagnus angustifolia, Ziziphora tenuior, Heracleum persicum and Scrophularia striata are among the most important medicinal plants in Iran with anticonvulsant effect. Additional information on the effects of these medicinal plants is as follows:

\section{Peganum harmala L.}

The results of one study showed that oral treatment with methanolic extract of $P$. harmala at $45 \mathrm{mg} / \mathrm{kg}$ for 15 days inhibited strychnine induced seizure, decreased the time at onset of seizure and its length, increased the duration of respiratory arrest pronouncedly. It was also observed that the extract of seed/phenytoin (21) decreased mortality in animals.

\section{Lavandula officinalis Chaix}

Lavandula officinalis extract at dozes of 200, 400 and $800 \mathrm{mg} / \mathrm{kg}$ in NMRI mice could reduce the severity and duration of attacks. It also eliminated the fifth phase of seizures completely (22).

\section{Matricaria chamomilla L.}

The study revealed that the hydroalcoholic extract of $M$. chamomilla at dozes of 800 and $1000 \mathrm{mg}$ delayed the onset of tonic-clonic seizures compared to the control group (treated with saline). It also significantly reduced the 24-h mortality rate compared to the control group (23).

\section{Tanacetum sonbolii Mozaff.}

The tonic-clonic seizures in the groups receiving the $T$. sonbolii hydroalcoholic extract at $1200 \mathrm{mg}$ were significantly reduced compared to the control group. Besides that, there was a statistically significant difference between the mean time of delay to onset of seizure between the groups receiving extract and the control group. Extract reduced the rate of mortality from seizure and prevented tonic-clonic seizures in several cases (24).

\section{Launaea acanthodes (Boiss.) Kuntze}

The results of one study showed that in the open box test, single doze of fraction caused a significant reduction in rearing, while such effect was not observed on motility. In addition, different dozes of ethanolic extract (100, 200 and $300 \mathrm{mg}$ ) and the aqueous fraction inhibited seizure attacks by increasing the delayed periods to the onset of anterior limbs clonus and tonic-clonic attacks (25). 


\section{Ocimum basilicum L.}

Mice in the $100 \mathrm{mg} / \mathrm{kg}$ dose group showed the most epileptic seizures. Mice in the two groups in receiving 100 and $250 \mathrm{mg} / \mathrm{kg}$ showed the highest and the lowest myoclonic contractions in comparison with other groups, respectively. In the group receiving $250 \mathrm{mg} / \mathrm{kg} 65$ minutes before injection of pentylenetetrazole, three factors, the number of seizures and mortality rate were significantly increased, decreased and decreased respectively (26).

\section{Salvia sahendica Boiss. \& Buhse}

The injection of hydroalcoholic extract of $S$. sahendica doze-dependently delayed the onset of clonic and tonic-clonic seizures. The doze of 600 $\mathrm{mg} / \mathrm{kg}$ BW was the most effective doze on the quantity of seizure. Extract administration also reduced the time of tonic-clonic seizure in mice and also significantly reduced the mortality and the number of animals' sudden jumps during seizure (27).

\section{Ruta graveolens $\mathrm{L}$.}

The study in NMRI mice showed that the hydroalcoholic extract of $R$. graveolens in a dozedependent manner, increased the delay in the onset of myoclonic seizures. Delay in myoclonic seizure was significant at dozes of 300, 500, 800 and $1000 \mathrm{mg} / \mathrm{kg}$ compared to the control group. Delay in tonic-clonic seizure was observed at the doze of 100, as well as in doses of 300,500, 800 and $1000 \mathrm{mg} / \mathrm{kg}$ was significant compared to the control group (28).

\section{Elaeagnus angustifolia $\mathrm{L}$.}

The study on male mice showed that hydroalcoholic extract of E. angustifolia at 200 and $400 \mathrm{mg} / \mathrm{kg}$ increased the threshold of induced seizure significantly compared to control group of male mice (29).

\section{Ziziphora tenuior $\mathrm{L}$.}

The results of a study in a mouse model showed that injections of hydroalcoholic extract of $Z$. tenuior in a dose-dependent manner delayed the onset of clonic, tonic, and generalized tonic-colonic seizures, with the highest effects observed at 600 and $900 \mathrm{mg} / \mathrm{kg}$ of the extract. Besides, administration of hydroalcoholic $Z$. tenuior extract leaves caused a decrease in the average time of clonic, tonic and tonic-clonic seizure in animals. The extract also protected the animals against mortality and the number of sudden jerks, with the greatest effect observed at 600 and $900 \mathrm{mg} / \mathrm{kg}$ (30).

\section{Heracleum persicum Desf. ex Fisch.}

Experiment with the mice showed that hydroalcoholic extract of $H$. persicum leaves at 300 and $600 \mathrm{mg} / \mathrm{kg}$ caused an increase in the tonic phase. In the tonic-clonic phase, the increase in seizure threshold was only significant at 600 $\mathrm{mg} / \mathrm{kg}$. The hydroalcoholic extract of $H$. persicum leaves significantly reduces the mean survival time in tonic and tonic-clonic seizures (31).

\section{Scrophularia striata Boiss.}

The hydroalcoholic extract of $S$. striata in mice showed that at 300,600 and $900 \mathrm{mg} / \mathrm{kg}$ delayed the onset of tonic, clonic and tonic-clonic seizures and also reduced the incidence of imbalance and jump in animals at birth. Injection of the hydroalcoholic extract of the plant resulted in the decrease of mortality rate to zero (32).

\section{Discussion}

Seizure is one of the most common and warning symptoms of brain diseases, which often informs the serious damage to the brain parenchyma. Accordingly, in Iran, medicinal plants such as Peganum harmala, Lavandula officinalis, Matricaria chamomilla, Tanacetum sonbolii, Launaea acanthodes, Ocimum basilicum, Salvia sahendica, Ruta graveolens, Elaeagnus angustifolia, Ziziphora tenuior, Heracleum persicum and Scrophularia striata are among the most important medicinal plants with anticonvulsant effect. The main alkaloid of this plant is a substance called harmalin (33). Various scientific studies have shown that the seeds of $P$. harmala have appetizing and diuretic properties and are involved in the treatment of neurological diseases $(34,35)$. Several studies on the effects of $L$. officinalis have reported the effects of the plant in reducing seizures and epileptic attacks (36-38). Compounds such as butyric acid, cinnamol, nerol, borneol, propionic acid, valeric acid, free linalool, tanin and flavonoids exist in L. officinalis (39). T. sonbolii is rich in antioxidants such as flavonoids, polyphenols and essential fatty oils, which have been shown to have antioxidant effects and to contribute to weakening the central nervous system (40). T. sonbolii contains certain compounds belonging to the sesquiterpenes, lactones and flavonoids (41).

In the recent studies, the possible effect of flavonoids on the central nervous system through binding benzodiazepine receptors as that of benzodiazepines has been reported. This argument has been raised according to evidence on the effect of flavonoids in creating sleepiness, removal of anxiety and control of seizure (42-44). Studies have shown that the activation of benzodiazepine receptors by stopping the epileptic seizures by strengthening the brain's gababaretic system (45). Polyphenols also have a positive effect on the treatment of many diseases such as cancers, cardiovascular diseases, and nervous system diseases (46). Since ancient times, gum derived from the stems of $L$. acanthodes has been used among the populations of desert areas as an effective herbal remedy for the treatment of many diseases, such as epilepsy, neurological diseases, local and joint pains (47). The basil has long been used as sedative, 
analgesic and anticonvulsant in traditional medicine (48). The main constituents in Ocimum basilicum are 1, 8 cineoles, linalool and geraniol, which comprise $93 \%$ of essential oils (49). Compounds such as glycosides, coumarins, quinoline alkaloids, flavonoids and lignins are phytochemicals identified in Ruta graveolens (50). Elaeagnus angustifolia has analgesic, anti-inflammatory and restorative effects (51-55). The Elaeagnus angustifolia extract contains compounds such as cytosterol, cardiac glycosides, terpenoids and flavonoids (56). It has been shown that phytosterol and flavonoids have analgesic and anti-inflammatory effects (57). Ziziphora tenuior leaves are traditionally useful in improving seizures, respiratory diseases for sedative, antispasmodic and anticonvulsant, antismooth muscle spasm and anti-flatulence effects (5860). The main compound of the leaf of $H$. persicum is trans-anthole (61). Medicinal plants can be effective in improving seizure symptoms due to their active and antioxidant ingredients and they can be used to produce effective drugs on seizure.

\section{Acknowledgements}

The authors are grateful to the Shahrekord University of Medical Sciences, Iran for financial assistance.

\section{Authors' contributions}

All the authors contributed equally to the work presented in this paper.

\section{Competing Interests}

The authors declared that they have no conflict of interest.

\section{References}

1. Carvey PM. Drugs action in the central nervous system. Oxford Univ Press 1998; 201.

2. White H.S., Significance of animal seizure models and mechanism of action studies of potential antiepileptic drugs. Epilepsia 1997; 38(Suppl. 1): 9-17. https://doi.org/10.1111/j.1528-1157.1997.tb04523.x

3. Lott RS, Mcauley JW. Seizure disorders. In: Koda Kimble MA. Yourg LY. Applied therapeutics: the clinical use of drugs. 7th ed. Baltimore: Lippincott Williams \& Wilkins; 2001: 52-102.

4. Porter RJ, Meldrum BS. Katzung BG. Antiseizure drugs. In: Basic and clinical pharmacology. New York: Lange Medical Books. McGraw Hill 2001; 345-48.

5. McNamara JO Cellular and molecular basis of epilepsy. J $\begin{array}{llll}\text { Neuro Sci 1994; } & \text { 14(6): } & 3413-25\end{array}$ https://doi.org/10.1523/INEUROSCI.14-06-03413.1994

6. Olney J. Excitatory amino acids and neuropsychiatric disorders. Biological Psychiatry 1989; 26: 505-25. https:// doi.org/10.1016/0006-3223(89)90072-3

7. Blumcke I, Beck H, Lie AA, Wiestler OD. Molecular neuropathology of human mesial temporal lobe epilepsy. Epilepsy Res 1999; 36: 205-23. https://doi.org/10.1016/S0920-1211(99)00052-2

8. Crvey PM. Drug's action in the central nervous system. New York, Oxford University Press, 1998: 201.

9. Leung $\mathrm{AY}$ and Foster S. Encyclopedia of common natural ingredients. New York, Willey Interscience Publication 1996: 145-7, 368-71, 382-83.

10. Westbrook GL, Lothman EW. Cellular and synaptic basis of kainic acid-induced hippocampal epileptiform activity. Brain Res 1983; 273: 97-109. https://doi.org/10.1016/0006-8993(83)91098-3

11. Reyes-Garcia V. The relevance of traditional knowledge systems for ethnopharmacological research: theoretical and methodological contributions. J Ethnobiol Ethnomed. 2010;6:32 https://doi.org/10.1186/1746-4269-6-32

12. Shoohani B, Hemati AA, Taheri Moghadam M. Effects of Scrophularia striata extract on Wound Healing in Rabbit. J Ilam Univ Med Sci 2010; 17(4): 9-16.

13. Kim HJ, Jee EH, Ahn KS, Choi HS, Jang YP. Identification of marker compounds in herbal drugs on TLC with DART-MS. Arch Pharm Res 2010; 33(9): 1355-59. https://doi.org/10.1007/s12272-010-0909-7

14. Faryadian S, Sydmohammadi A, Khosravi A., Kashiri M, Faryadayn P, Abasi N. Aqueous extract of Echlum amoenum elevate CSF serotonin and dopamine level in depression rat. Biomedical and Pharmacology Journal 2014; 7(1): 137-42

15. Valadi, A., Nasri, S., Abbasi, N., Amin, G.R Antinociceptive and anti-inflammatory effects of hydroalchoholic extract of Anethum graveolens L. seed. Journal of Medicinal Plants 2010; 9(34):124-30.

16. Bahmani, M., Khaksarian, M., Rafieian-Kopaei, M., Abbasi, N. Overview of the therapeutic effects of origanum vulgare and Hypericum perforatum based on Iran's ethnopharmacological documents. Journal of Clinical and Diagnostic Research 2018; 12(7): 1-4. https:// doi.org/10.7860/JCDR/2018/34177.11728

17. Shokri Z, Khoshbin M, Koohpayeh A, Abbasi N, Bahmani F, Rafieian-Kopaei, M, Beyranvand F. Thyroid diseases: Pathophysiology and new hopes in treatment with medicinal plants and natural antioxidants. International Journal of Green Pharmacy 2018; 12(3): 473-82.

18. Abbasi N, Mohammadpour S, Karimi E, Aidy A, Karimi P, Azizi M, Asadollahi K. Protective effects of smyrnium cordifolium boiss essential oil on pentylenetetrazolinduced seizures in mice: Involvement of benzodiazepine and opioid antagonists. Journal of Biological Regulators and Homeostatic Agents 2017; 31(3):683-89.

19. Tajbakhsh M, Karimi A, Tohidpour A, Abbasi N, Fallah F, Akhavan MM.The antimicrobial potential of a new derivative of cathelicidin from Bungarus fasciatus against methicillin-resistant Staphylococcus aureus. Journal of Microbiology 2018; 56(2): 128-37 https://doi.org/10.1007/s12275-018-7444-5

20. Hijikata Y, Yasuhara A, Yoshida Y, Sento S. Traditional Chinese medicine treatment of epilepsy. The Journal of alternative and complementary medicine 2006; 12: 67377. https://doi.org/10.1089/acm.2006.12.673

21. Hashemi A, Nayebi A, Sadegi MR, Faramarzi A, Delazar A, Rezazadeh H. Study of the methanolic extract of Peganum seeds on convulsion induced by strychnine in swiss mice. Pharmaceutical Sciences 2009; 15(3): 257-62. 
22. Rahmati B, Khalili M, Roghani M, Ahghari P. Anticonvulsant effect of hydro-alcoholic extract of Lavandula officinalis on seizures in pentylenetetrazolinduced kindling model in male mice. Daneshvar Medicine 2012; 19 (98): 25-32.

23. Rostampour M, Aghaei I, Solatani B, Khakpour B. Effect of Matricaria chamomile hydroalhcholic extract on PTZ induced seizure in male mice. J guilan Uni Med Sci 2014; 23 (89): 8-14.

24. Naderi F, Azhdari-ZarmehriH, Erami E, Sonboli A, Sofiabadi M, Mohammad-Zadeh M. The effect of Tanacetum sonbolii hydroalcholic extract on PTZ induced seizures in male Mice. J Med Plants 2012; 44; 11(4): 193-201.

25. Karimidokht shahrbabaki A, Oryan SH, Parivar K. Anticonvulsant activity of ethanolic extract and aqueous fraction of Launaea acanthodes gum in comparison with diazepam in mice. JQUMS 2009; 13(1): 50: $14-20$.

26. Modaresi M, Pouriyanzadeh A. Effect of Ocimum basilicum hydro alcoholic extract against pentylenetetrazole-induced seizure in mice. Yasouj Uni Med Sci J 2013; 18(8): 80: 615-22.

27. Azhdari-Zarmehri H, Naderi F, Erami E, MohammadZadeh M. Effects of Salvia sahendica hydroalcoholic extract on PTZ induced seizure in male mice. Koomesh 2013; 14 (4): 497-504.

28. Keihanian F, M. Rostampour Vajari, A. Saeidynia, A.R. Elmieh. Effect of Ruta graveolens hydro-alcoholic extract on pentylenetetrazole-induced seizure in male Mice. J Babol Univ Med Sci 2012; 14(4): 30-36. https://doi.org/10.1055/s-0032-1321336

29. Mirazi N, Hosseini AK. Effects of hydroethanolic extract of Elaeagnus angustifolia on pentylenetetrazole induced seizure in male mice. Medical Journal of Tabriz University of Medical Sciences and Health Services 2014; 36(1): 74-81.

30. Piri H, Alimohammadi B, Saeidi F, Naderi F, AzhdariZarmehri H. Anticonvulsant activity of hydroalcoholicextract of Ziziphora tenuior L. on pentylenetetrazol induced seizure in mice. Journal of Sabzevar University of Medical Sciences 2016; 23(1): 151-60.

31. Saeidi F, Azhdari Zarmehri H, Alimohammadi B1, Erami E. The Effect of hydroalcoholic extract of Heracleum persicum on pentylenetetrazol induced seizure in mice. Zanjan Uni Med Sci 2014; 21(86): 45-55.

32. Alimohammadi B., B, Azhdari-Zarmehri H, Sofiabadi M, Moslem A.R. Anticonvulsant effect of hydroalcoholic extract of Scrophularia striata Boiss. on pentylenetetrazol-induced seizure in mice. Kerman Uni Med Sci 2015; 21(3): 207-18.

33. Muhi-eldeen Z, Al-Shamma KJ, Al- Hussainy TM, AlKaissi EN, Al-Daraji AM, Ibrahim H. Acute toxicological studies on the extract of Iraqi Peganum harmala in rats. European Journal of Scientific Research 2008; 22: 494500.

34. Bown D. Encyclopedia of Herbs and Their Uses. New York: DK Publishing, Inc., 1995; 265.

35. Shi C, Chen S, Wang G, Liao J, Chen C. Vasorelaxant effect of Harman. European Journal of Pharmacology 2000; 390: 319-25. $\quad$ https://doi.org/10.1016/S00142999(99)00928-0

36. Salah SM, Jager AK. Screening of traditionally used Lebanese herbs for neurological activities. Journal of Ethnopharmacology 2005; 97(1): 145-49. https://doi.org/10.1016/j.jep.2004.10.023
37. Shahriyari H, Ersali A, Rahmanifard M. Anticonvulsant effect of Lavandula officinalis in two epilepsy animal model. Journal of Iran Medical Basic Sciences 2004; 8(3):172-78.

38. Merabani M, Modirian E, Ebrahimabadi AR, Shahnavaz S, Vafazadeh S, Heidari MR. The effect of hydro methanolic extract of Lavandula vera DC and Cuscuta epithymum Murr on the seizure induced by pentylene tetrazole in mice. Kerman: Physiology and Pharmacology Research Center 2006; 14(1): 25-35.

39. Barazandeh MM. Essential oil composition of Lavandula latifolia Medik from Iran. J Essent Oil Res 2002; 103: 412. https://doi.org/10.1080/10412905.2002.9699784

40. Sofiabad M, Esmaeili MH, Haghdoost- Yazdi H, AzhdariZarmehri $\mathrm{H}$. The prenatal consumption of aqueous extract of Glycyrrhiza glabra, improves memory retrieval in mice. J. Medicinal Plants 2011; 10 (38): 49-54

41. Esmaeili MA, Sonboli A and Ayyari Noushabadi M. Antioxidant and protective properties of six Tanacetum species against hydrogen peroxide-induced oxidative stress in K562 cell line: A comparative study. Food Chem. 2010;121(1): 148-55. https://doi.org/10.1016/j.foodchem.2009.12.022

42. Fernandez SP, Wasowski C, Loscalzo LM, Granger RE, Johnston GA, Paladini AC, et al. Central nervous system depressant action offlavonoid glycosides. Eur. J. Pharmacol 2006; 539:168-76. https://doi.org/10.1016/j.ejphar.2006.04.004

43. Marder $\mathrm{M}$ and Paladini AC. GABAA-receptor ligands of flavonoid structure. Curr. Top. Med. Chem 2002; 2: 85367. https://doi.org/10.2174/1568026023393462

44. Johnston GA. GABAA receptor channel pharmacology. Curr. Pharm. Des 2005; 11: 1867-85. https://doi.org/10.2174/1381612054021024

45. Smsam Shariat A. Agenda of Medicinal Plants Laboratory. Isfahan University Press, 1989; 18-20.

46. Ruffels J and Griffin M. Activation of ERK1/2, JNK and PKBby hydrogen peroxide in human SHSY5Y neuroblastoma cells: Role of ERK1/2in H2O2-induced cell death. European Journal of Pharmacology 2004; 483: 163-73. https://doi.org/10.1016/j.ejphar.2003.10.032

47. Mahmodi Y, Yasa N. Investigation of chemical structure of L. acanthodes (Bioss) O. Kontz flavonoids. La Pharmacology faculty, Tehran University, 1995; Tez number; 3346.

48. Kasture VS, Deshmukh VK, Chopde CT. Anxiolytic and anticonvulsive activity of Sesbania grandiflora leaves in experimental animals. Phytother Res 2002; 16(5): 45560. https://doi.org/10.1002/ptr.971

49. Lee SJ, Umano K, Shibamoto T, Lee KG. Identification of volatile components in basil (Ocimum basilicum L.) and thyme leaves (Thymus vulgaris L.) and their antioxidant properties . Food Chem 2005; 91: 131-37. https://doi.org/ $\underline{10.1016 / j . f o o d c h e m .2004 .05 .056}$

50. Momen Tonekaboni M. Tohfatolmomenin. 1st ed. Corrected by Rahimi R, Shams Ardakani MR, Farjadmand F. Tehran: Nashr Shahr Publications 2007; 241-42.

51. Ahmadiani A, Hosseiny J, Semnanian S, Javan M, Saeedi $\mathrm{F}$, Kamalinejad $\mathrm{M}$, et.al. Antinociceptive and antiinflammatory effects of Elaeagnus angustifolia fruit extract. Journal of Ethnopharmacology 2000; 72: 287-92. https://doi.org/10.1016/S0378-8741(00)00222-1

52. Wang Q, Ruan Xi, Huang JH, YAN Q.Ch. Intraspecific genetic relationship analyses of Elaeagnus angustifolia based on RP-HPLC biochemical markers. Journal of 
Zhejiang University SCIENCE B 2006; 7(4): 272-78. https://doi.org/10.1631/jzus.2006.B0272

53. Hosseinzadeh H, Ramezani M, Namjo N. Muscle relaxant activity of Elaeagnus angustifolia L. fruit seeds in mice. Journal of Ethnopharmacology 2003; 84(2-3): 275- 78. https://doi.org/10.1016/S0378-8741(02)00331-8

54. Gurbuz I, Ustun O, Yesilada E, Sezik E, Kutsal O. Antiulcerogenic activity of some plants used as folk remedy in Turkey. J Ethnopharmacol 2003; 88(1): 93-97. https://doi.org/10.1016/S0378-8741(03)00174-0

55. Mehrabani Natanzi M, Pasalar P, Kamalinejad M, Dehpour A.R, Tavangar S.M, Sharifi R, et al., Effect of aqueous extract of Elaeagnus angustifolia fruit on experimental cutaneous wound healing in rats. Acta Medica Iranica 2012; 50(9): 589-96.

56. Dembińska-Migas W, Gill S. Flavonoids in leaves of Elaeagnus angustifolia L. Pol J Pharmacol Pharm 1973; 25(6): 599-606.
57. Muthiah NS, Vijayasekaran V. Anti-inflammatory activity of flavone and its methoxy derivative: structure activity study. Ind J Pharmac Sci 1993; 55: 180-83.

58. Yazdani D, Shahnazi S, Jamshidi A, Reza Zadeh S, Mojab F. Study on variation of essential oil quality and quantity in dry and fresh herb of Thyme and Tarragon. Med Plants 2005; 5:132.

59. Akhandzadeh S. Encylopedia of Iranian Medicinal Plants. Tehran: Arjmand; 2000.

60. Amin G. Traditional Medicinal Plants of Iran: Institute of Medicinal Plant Research, 1991.

61. Sedaghat M, Dehkordi AS, Abai M, Khanavi M, Mohtarami F, Abadi YS, et al. Larvicidal activity of essential oils of Apiaceae plants against Malaria vector, Anopheles stephensi. Iran J Arthropod Borne Dis 2011; 5: 51-59. 